\title{
On the Mesophase Formation of 1,3-Dialkylimidazolium lonic Liquids
}

\author{
Mei Yang, Bert Mallick, and Anja-Verena Mudring* \\ Anorganische Chemie III - Materials Engineering and Characterization, Fakultät für Chemie and Biochemie, Ruhr-Universität
Bochum, 44780, Bochum, Germany
}

Supporting Information

\begin{abstract}
A series of seven different 1,3-dialkylimidazoliumbased ion-pair salts with the same molecular weight and size but different symmetries was synthesized. For all salts, bromide was chosen as the counterion, giving the series ( $[\mathrm{CnIMCm}][\mathrm{Br}])$, where IM = imidazolium and $\mathrm{C} n$ and $\mathrm{Cm}$ are varying $N$-alkyl substituents with $n+m=13$. Thus, the effect of symmetry on the physicochemical properties, such as thermal transitions, densities and viscosities and particularly mesophase formation, is investigated herein. All salts are fully characterized by NMR spectroscopy and mass spectrometry, and their physicochemical properties such as thermal transitions, densities, and viscosities are reported. Single crystal X-ray structure analysis is reported for 1-tridecylimidazolium bromide ([COIMC13][Br]) and 1-ethyl-3-undecylimidazolium bromide ([C2IMC11][Br]). Salts 1-tridecylimidazolium bromide

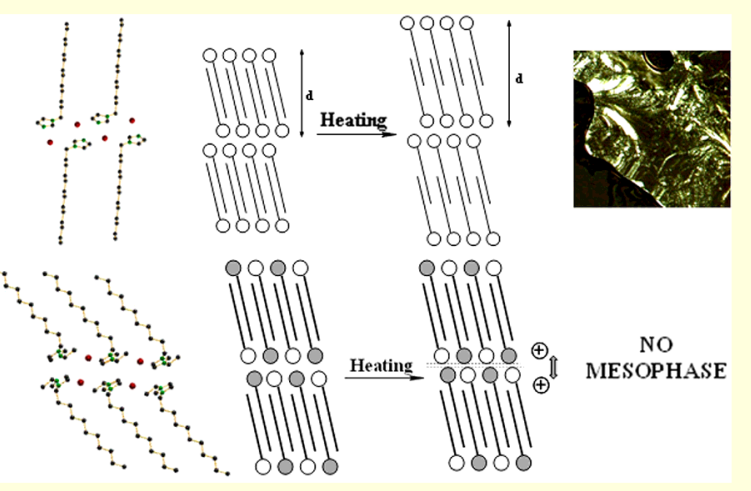
([CoIMC13][Br] ) and 1-dodecyl-3-methylimidazolium bromide ([C1IMC12][Br]) exhibit thermotropic liquid crystal behavior, confirmed by differential scanning calorimetry, polarized optical microscopy, and small-angle X-ray diffraction to be the SmA mesophase. A structure with interdigitation of alkyl chains is observed for all of [COIMC13][Br], [C1IMC12][Br], and [C2IMC11][Br], despite the absence of thermotropic liquid crystalline behavior for the latter (and all other isomers with an alkyl chain length less than 12 carbon atoms). This allows us to draw the conclusion that for the liquid crystal phase of an ionic liquid to exist, not only are the calamitic shape and integral length of a molecule important but a minimal alkyl chain length of $n=12$ is also required. Therefore, a dodecyl group could be considered as the functional group responsible for liquid crystalline behavior.
\end{abstract}

\section{INTRODUCTION}

Ionic liquid crystals (ILCs) combine the self-organization features of liquid crystals (LCs) and the solvent properties of ionic liquids (ILs). "Liquid crystals" are substances which have properties at an intermediate stage between the perfectly ordered periodic structure of crystalline solids and the completely disordered structure of isotropic liquids, gases and amorphous solids. Such an intermediate state of matter is called a "mesomorphic state", the physical and chemical properties of which, can be influenced by the orientations of LC molecules. ${ }^{2}$ Thermotropic LCs, which are able to form mesophases when the temperature is varied, have been very intensively investigated. A typical thermotropic LC is composed of rodor disc-shaped molecules. ${ }^{3}$ Nowadays, liquid crystalline materials can be found in a wide range of applications, such as in the manufacturing of displays, molecular sensors and detectors, and as highly ordered solvents for many chemical reactions. ${ }^{4}$ ILs are salts with a melting point at or below 100 ${ }^{\circ} \mathrm{C}$. ILs have become the subject of a large amount of research over last decades. ${ }^{6}$ The ability to change chemical and physical properties by specific cation-anion combinations has led to their promotion as "designer solvents". Because of their unique properties such as nonvolatility, high thermal stability and nonflammability, ILs have been used in a wide variety of applications, such as organic solvent replacements, thermal fluids, gas storage, and chemical synthesis and catalysis. ${ }^{7}$

Imidazolium based ILs represent the most studied system so far. Holbrey and Seddon reported the thermal behavior of 1alkyl-3-methylimidazolium based ILs. A mesophase formation was observed when the substituted alkyl chain bore 12 or more carbon atoms in combination with anions such as $\mathrm{Cl}^{-}, \mathrm{Br}^{-}$and $\mathrm{BF}_{4}{ }^{-}$but not bis(trifluoromethylsulfonyl)imide $\left(\mathrm{NTf}_{2}{ }^{-}\right){ }^{8}$ 1Dodecyl-3-methylimidazolium is considered as one of the most well-known example of rod shaped ILC cations, ${ }^{9}$ yet the choice of anion remains important The driving forces for the formation of mesophases in thermotropic ILCs are, for example, hydrophobic interactions between large alkyl groups including van der Waals interactions; Coulombic forces between ions; dipole-dipole interactions; hydrogen bonding and cation $-\pi$ interactions as well as $\pi-\pi$ stacking of the commonly used aromatic core groups etc. ${ }^{1,10}$ Only a balance of all these interactions could promise the formation of a mesophase. All these intermolecular forces are also displayed in conventional ILs and can be influenced by cation/anion combinations and geometrical factors of both ions. For

Received: March 27, 2013

Revised: $\quad$ May 27, 2013

Published: May 28, 2013 
example, formation of mesophase was observed for the salt 1methyl-3-octylimidazolium octylsulfonate [C1IMC8] $\left[\mathrm{C}^{-} \mathrm{SO}_{3}\right]$, in which an amphiphilic character is imparted into both the cation and anion. ${ }^{11,12}$ Therein, the synergistic effect of cation and anion are seen, as separately these are rather poor amphiphiles. Furthermore, changing cation geometries can also provide the opportunity to diversify the physiochemical properties of ILs, such as varying the polar and nonpolar domains. Indeed, the segregation of nonpolar and polar regions in ILs, previously demonstrated by molecular dynamics simulations ${ }^{13}$ and coarse-grain modeling, ${ }^{14}$ dictates their ability to interact with given solutes. For this reason ILs are regarded as highly structured solvents and have already been used in size controlled nanoparticle synthesis. ${ }^{13-15}$

By studying these interactions in ILs it is hoped to gain fundamental insights into the structures of ILCs, which is clearly required for rational design of ILCs for further applications. A fundamental question needs to be answered here: how does one design a cation topology that accompanied by a suitable anion results in an IL capable of forming a mesophase? What are the necessary factors for an ionic mesophase formation?

Symmetrical 1,3-dialkylimidaolium based ILs with dialkyl moieties ranging from dimethyl to bisdecyl have been reported as hexafluorophosphate salts, ${ }^{16}$ and the bisdodecyl analogue as the perchlorate and tetrafluoroborate salt. ${ }^{17}$ Only for the bisdodecyl imidazolium IL a mesophase formation is reported, not for the lighter cations. Interestingly, the dihexyl $\mathrm{IL}$ forms a crystalline phase, while dipentyl forms a RTIL (room temperature ionic liquid) with a low temperature glass transition. Between diheptyl and dioctyl, a drastic drop in melting point is observed alongside a poorer tendency to crystallize for the odd-numbered chain lengths. It could be that asymmetric cations with similar molecular size and weight possess properties intermediate to the reported symmetrical species and perhaps form a mesophase. Therefore, herein we report a series of ILs with asymmetric cations, all of which are structural isomers of 1-dodecyl-3-methylimidazolium. The rodshaped molecule 1-dodecyl-3-methylimidazolium, has an integral length equal to 13 methyl/methylene carbons and an imidazolium headgroup. In our present study, we synthesize and characterize a series of 1,3-dialyklimidazolium ILs with an identical integral length but different symmetries (Scheme 1). As counterion, bromide was chosen. Hence, the physicochemical properties such as thermal transitions, densities and viscosities can be compared for ILs with same size and shape, but different symmetries.

For convenience, the salts are named by the number of carbon atoms in the two alkyl chains at the first and third positions of the imidazolium ring. For example, [C4IMC9 $]^{+}, 1-$ butyl-3-nonylimidazolium, as $\mathrm{C} 4 \mathrm{C} 9$ and [C6IMC7 $]^{+}, 1$-hexyl-3heptylimidazolium, as $\mathrm{C} 6 \mathrm{C} 7$.

\section{EXPERIMENTAL SECTION}

2.1. Sample Preparation. The synthesis and sample handling of anhydrous salts were carried out using standard Schlenk and argonglovebox techniques. All the bromide salts were hygroscopic. The samples were dried under $10^{-6} \mathrm{mbar}$ at $60^{\circ} \mathrm{C}$ for 3 days. The water content was determined by Karl Fischer titration. In all cases the water content was below $50 \mu \mathrm{g} / \mathrm{g}$.

2.2. Synthesis. Acetonitrile (99.5\%), ethyl acetate (95\%), methanol (99\%), dichloromethane (99.9\%), and tetrahydrofuran (extra dry, $>99 \%$ ) were used as received from J.T. Backer (Deventer, Holland). Hydrobromic acid (47\%) was obtained from Merck
Scheme 1. Different Types of Ionic Liquid Cations under Investigation, Bromide Was Used as Counter Ion

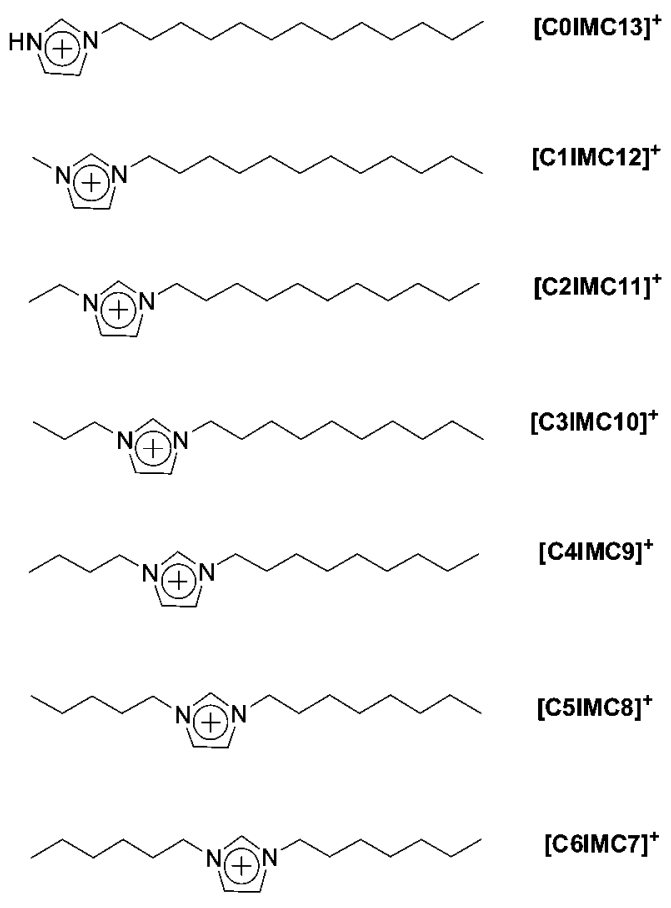

(Darmstadt, Germany). 1-Hexylimidazole (98\%) and 1-octylimidaole (98\%) were purchased from IoLiTec (Heilbronn, Germany). 1Ethylimidazole (95\%), 1-butylimidazole (98\%), imidazole (99.5\%), sodium hydride (95\%) and the all 1-bromoalkanes were purchased from Sigma-Aldrich (Steinheim, Germany). All the chemicals were used as received without further purification.

Synthesis of 1-alkylimidazole is outlined in Scheme 2. The procedures were modified from a reported method. ${ }^{18}$ The synthesis of 1-propylimidazole is as an example reported below.

Scheme 2. Synthesis of 1-Alkylimidazole

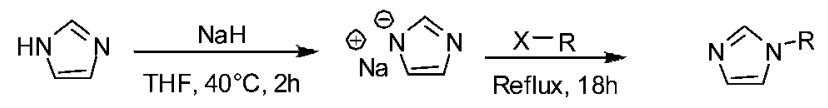

$\mathrm{NaH}(1.8 \mathrm{~g}, 70.2 \mathrm{mmol})$ suspended in anhydrous THF $(\sim 50 \mathrm{~mL})$ was added to a $100 \mathrm{~mL}$ flask. Upon addition of imidazole $(3.7 \mathrm{~g}, 54$ $\mathrm{mmol}$ ) hydrogen gas evolution set in. The reaction mixture was stirred at $40{ }^{\circ} \mathrm{C}$ until the gas evolution ceased. Then 1-bromopropane (4.4 $\mathrm{mL}, 5.9 \mathrm{~g}, 48 \mathrm{mmol}$ ) was added and the reaction mixture was heated under reflux $\left(70^{\circ} \mathrm{C}\right)$ overnight. After cooling to room temperature the solid precipitate was filtered off. The filtrate was concentrated under reduced pressure. A light brown oil was yielded and redissolved in $\mathrm{CH}_{2} \mathrm{Cl}_{2}$. Then the $\mathrm{CH}_{2} \mathrm{Cl}_{2}$ phase was washed three times with water. The organic phase was dried over sodium sulfate. After filtration, the solvent was removed via rotary evaporation. The product was dried under vacuum overnight to give a yellow-brownish oil. Yield $=4.6 \mathrm{~g}$, $41.6 \mathrm{mmol}, 77 \%$. ${ }^{1} \mathrm{H}$ NMR $\left(298 \mathrm{~K}, 200 \mathrm{MHz}, \mathrm{DMSO}-d_{6}\right): \delta[\mathrm{ppm}]=$ $0.80(3 \mathrm{H}, \mathrm{t}), 1.71(2 \mathrm{H}, \mathrm{sx}), 3.89(2 \mathrm{H}, \mathrm{t}), 6.87(1 \mathrm{H}, \mathrm{s}), 7.12(1 \mathrm{H}, \mathrm{s})$, $7.58(1 \mathrm{H}, \mathrm{s})$.

1-Tridecylimidazole was produced from imidazole $(0.6 \mathrm{~g}, 9 \mathrm{mmol})$ and 1-bromotridecane $(2.4 \mathrm{~mL}, 2.5 \mathrm{~g}, 9.5 \mathrm{mmol})$ with the general procedure. Yield $=1.9 \mathrm{~g}, 7.6 \mathrm{mmol}, 85 \% .{ }^{1} \mathrm{H}$ NMR $(298 \mathrm{~K}, 200 \mathrm{MHz}$, DMSO- $\left.d_{6}\right): \delta[\mathrm{ppm}]=0.84(3 \mathrm{H}, \mathrm{t}), 1.22(22 \mathrm{H}, \mathrm{s}), 1.70(2 \mathrm{H}, \mathrm{qn})$, $3.91(2 \mathrm{H}, \mathrm{t}), 6.85(1 \mathrm{H}, \mathrm{s}), 7.11(1 \mathrm{H}, \mathrm{s}) 7.57(1 \mathrm{H}, \mathrm{s})$.

The bromide salts were made via direct alkylation of the respective 1-alkylimidazole with alkyl bromide in a 1:1.1 molar ratio in acetonitrile (Scheme 3$)^{1 \mathrm{~b}}$ The reaction mixture was heated for two to three days at $90^{\circ} \mathrm{C}$. Afterward, the products were purified by 
Scheme 3. Synthesis of 1,3-Dialkylimidazolium Bromides

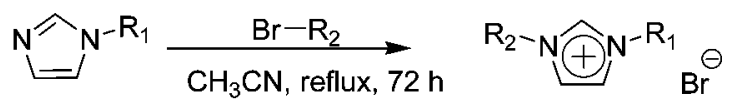

crystallization. For this, the crude products in solution were added dropwise to cold ethyl acetate $\left(T \approx-30^{\circ} \mathrm{C}\right)$. The crystalline products were then dried at room temperature for several days under dynamic vacuum. The preparation of $[\mathrm{C} 3 \mathrm{C} 10] \mathrm{Br}$ is given in detail as representative procedure for synthesis of 1,3-dialkylimidazolium bromides.

1-Propylimidazole $(2.0 \mathrm{~g}, 18.1 \mathrm{mmol})$ was dissolved in $30 \mathrm{~mL}$ of acetonitrile. 1-Bromodecane $(3.8 \mathrm{~mL}, 4.0 \mathrm{~g}, 20 \mathrm{mmol})$ was added dropwise and the reaction mixture was heated under reflux for $72 \mathrm{~h}$. By the end of the reaction, the solution changed color from pale yellow to brown. The hot reaction mixture was added to cold $\left(-30^{\circ} \mathrm{C}\right)$ ethyl acetate $(300 \mathrm{~mL})$. The product precipitated as a white powder. Afterward, the product was filtered under inert environment, washed repeatedly with ethyl acetate and dried in vacuum for at least 3 days at $60{ }^{\circ} \mathrm{C}$. Yield $=4.9 \mathrm{~g}, 14.7 \mathrm{mmol}, 81 \% .{ }^{1} \mathrm{H}$ NMR $(298 \mathrm{~K}, 200 \mathrm{MHz}$, DMSO- $\left.d_{6}\right): \delta[\mathrm{ppm}]=0.81(6 \mathrm{H}, \mathrm{m}), 1.19(15 \mathrm{H}, \mathrm{m}), 1.76(4 \mathrm{H}, \mathrm{m})$, $4.11(4 \mathrm{H}, \mathrm{m}), 7.74(2 \mathrm{H}, \mathrm{s}), 9.17(1 \mathrm{H}, \mathrm{s})$. ESI-MS (positive, $([\%])) \mathrm{m} /$ $z=251.1[\mathrm{M}-\mathrm{Br}]^{+}(100)$.

[C1C12] Br was synthesized from 1-methylimidazole $(5 \mathrm{~g}, 60$ $\mathrm{mmol})$ and 1-bromododecane $(8.3 \mathrm{~g}, 6.7 \mathrm{mmol})$. Yield $=18.0 \mathrm{~g}, 54$ mmol, 91\%. ${ }^{1} \mathrm{H}$ NMR $\left(298 \mathrm{~K}, 200 \mathrm{MHz}, \mathrm{DMSO}-d_{6}\right) \delta[\mathrm{ppm}]=0.82$ $(3 \mathrm{H}, \mathrm{t}), 1.20(17 \mathrm{H}, \mathrm{m}), 1.74(2 \mathrm{H}, \mathrm{t}), 3.81(\mathrm{~s}, 3 \mathrm{H}), 4.17(2 \mathrm{H}, \mathrm{t}), 7.61$ $(2 \mathrm{H}, \mathrm{s}), 9.27(1 \mathrm{H}, \mathrm{s})$. ESI-MS (positive, $([\%])) \mathrm{m} / z=251.1[\mathrm{M}-$ $\mathrm{Br}]^{+}(100)$.

[C2C11]Br was synthesized from 1-ethylimidazole (3 g, 29.6 $\mathrm{mmol})$ and 1-bromoundecane $(7.1 \mathrm{~g}, 30.0 \mathrm{mmol})$. Yield $=8.5 \mathrm{~g}, 25.6$ mmol, 86\%. ${ }^{1} \mathrm{H}$ NMR $\left(298 \mathrm{~K}, 200 \mathrm{MHz}\right.$, DMSO- $\left.d_{6}\right) \delta[\mathrm{ppm}]=0.84$ $(3 \mathrm{H}, \mathrm{t}), 1.23(17 \mathrm{H}, \mathrm{m}), 1.41(3 \mathrm{H}, \mathrm{t}), 1.78(2 \mathrm{H}, \mathrm{t}), 4.17(4 \mathrm{H}, \mathrm{qu}), 7.82$ $(2 \mathrm{H}, \mathrm{s}), 9.27(1 \mathrm{H}, \mathrm{s})$. ESI-MS (positive, $([\%])) \mathrm{m} / z=251.1[\mathrm{M}-$ $\mathrm{Br}]^{+}(100)$.

[C4C9] Br was synthesized from 1-butylimidazole ( $3 \mathrm{~g}, 23.7 \mathrm{mmol})$ and 1-bromononane $(5.18 \mathrm{~g}, 25 \mathrm{mmol})$. Yield $=6.3 \mathrm{~g}, 19.0 \mathrm{mmol}$, $80 \% .{ }^{1} \mathrm{H}$ NMR $\left(298 \mathrm{~K}, 200 \mathrm{MHz}\right.$, DMSO- $\left.d_{6}\right): \delta[\mathrm{ppm}]=0.89(6 \mathrm{H}$, m), $1.23(15 \mathrm{H}, \mathrm{m}), 1.78(4 \mathrm{H}, \mathrm{qn}), 4.18(4 \mathrm{H}, \mathrm{dt}), 7.84(2 \mathrm{H}, \mathrm{s}), 9.35$ $(1 \mathrm{H}, \mathrm{s})$. ESI-MS (positive, $([\%])) \mathrm{m} / z=251.1[\mathrm{M}-\mathrm{Br}]^{+}(100)$.

$[\mathrm{CSC}] \mathrm{Br}$ was synthesized from 1-octylimidazole $(2 \mathrm{~g}, 16.4 \mathrm{mmol})$ and 1-bromopentane $(2.7 \mathrm{~g}, 18 \mathrm{mmol})$. Yield $=3.9 \mathrm{~g}, 11.6 \mathrm{mmol}, 70 \%$. ${ }^{1} \mathrm{H}$ NMR $\left(298 \mathrm{~K}, 200 \mathrm{MHz}, \mathrm{DMSO}-d_{6}\right): \delta[\mathrm{ppm}]=0.82(6 \mathrm{H}, \mathrm{m})$, $1.20(15 \mathrm{H}, \mathrm{m}), 1.76(4 \mathrm{H}, \mathrm{qn}), 4.13(4 \mathrm{H}, \mathrm{t}), 7.73(2 \mathrm{H}, \mathrm{s}), 9.14(1 \mathrm{H}, \mathrm{s})$. ESI-MS (positive, $([\%])) \mathrm{m} / z=251.1[\mathrm{M}-\mathrm{Br}]^{+}(100)$.

$[\mathrm{C} 6 \mathrm{C} 7] \mathrm{Br}$ was synthesized from 1-hexylimidazole $(3 \mathrm{~g}, 19 \mathrm{mmol})$ and 1-bromoheptane $(3.8 \mathrm{~g}, 21 \mathrm{mmol})$. Yield $=3.3 \mathrm{~g}, 9.8 \mathrm{mmol}, 52 \%$. ${ }^{1} \mathrm{H}$ NMR $\left(298 \mathrm{~K}, 200 \mathrm{MHz}, \mathrm{DMSO}-d_{6}\right): \delta[\mathrm{ppm}]=0.85(6 \mathrm{H}, \mathrm{t}), 1.25$ $(15 \mathrm{H}, \mathrm{m}), 1.79(4 \mathrm{H}, \mathrm{qu}), 4.17(4 \mathrm{H}, \mathrm{t}), 7.82(2 \mathrm{H}, \mathrm{s}), 9.27(1 \mathrm{H}, \mathrm{s})$. ESIMS (positive, $([\%])) m / z=251.1[\mathrm{M}-\mathrm{Br}]^{+}(100)$.

$[\mathrm{COC} 13] \mathrm{Br}$ was prepared by adding dropwise a slight excess of concentrated hydrobromic acid $(1 \mathrm{~mL}, 48 \%, 11 \mathrm{mmol})$ to 1 tridecylimidazole $(1.5 \mathrm{~g}, 5.9 \mathrm{mmol})$ at $0{ }^{\circ} \mathrm{C}$ in diethyl ether. The bromide salt precipitated as white solid immediately. This solid was purified by successive washing with cold ether, followed by vacuum drying. Yield $=1.6 \mathrm{~g}, 4.6 \mathrm{mmol}, 78 \% .{ }^{1} \mathrm{H}$ NMR $(200 \mathrm{MHz}, \mathrm{DMSO}-$ $\left.d_{6}\right): \delta[\mathrm{ppm}]=0.84(3 \mathrm{H}, \mathrm{t}), 1.23(20 \mathrm{H}, \mathrm{m}), 1.78(2 \mathrm{H}, \mathrm{t}), 4.17(2 \mathrm{H}, \mathrm{t})$, $7.68(1 \mathrm{H}, \mathrm{s}), 7.78(1 \mathrm{H}, \mathrm{s}), 9.13(1 \mathrm{H}, \mathrm{s})$. ESI-MS (postive, $([\%])) \mathrm{m} / \mathrm{z}$ $=251.3[\mathrm{M}-\mathrm{Br}]^{+}(100)$.

2.3. Rheological Measurements. Rheological measurements were performed on a stress-controlled rheometer (RheoStress75, Thermo Fisher Scientfic Inc., St. Louis, MO) with CR (controlled rate)-mode under argon atmosphere. Oscillatory shear measurements were performed using a parallel plate geometry with a $20-\mathrm{mm}$ diameter PP20-sensor on rotor and 21-mm-diameter PP20-sensor on stator. The gap between the plates is $1 \mathrm{~mm}$. After each heating process the sample was kept for $10 \mathrm{~min}$ on the plate to reach equilibrium. The temperature was regulated within $\pm 0.1{ }^{\circ} \mathrm{C}$.
2.4. Crystal Structure Analysis. Crystals of [ $\mathrm{COC} 13] \mathrm{Br}$ were obtained from recrystallization of the salt in dichloromethane and diethyl ether. Crystals of $[\mathrm{C} 2 \mathrm{C} 11] \mathrm{Br}$ were obtained from cooling the molten salt to room temperature. Suitable single crystals were sealed in Lindeman glass capillaries. All data were collected on a Stoe IPDS-I single-crystal X-ray diffractometer with graphite monochromated Mo $\mathrm{K} \alpha$ radiation $(\lambda=0.71073 \AA$ at $100 \mathrm{~K})$. Crystal structure solution by direct methods using SIR 92 yielded the heavy atom positions. Refinement with SHELXL-97 allowed for the localization of the remaining atom positions. Hydrogen atoms were added and treated with the riding atom mode. Data reduction was carried out with the program package X-Red and numerical absorption correction was carried out with the program X-Shape. To illustrate the crystal structures, the program Diamond 3 was used.

2.5. Temperature-dependent SAXS Experiments. SAXS (small-angle X-ray scattering) measurements were carried out at the A2 Beamline of DORIS III, Hasylab, DESY, Hamburg, Germany, at a fixed wavelength of $1.5 \AA$. The data were collected with a MarCCD detector. The detector was calibrated with silver behenate. The sample-detector position was fixed at $635.5 \mathrm{~mm}$. For measurements, the samples were placed in a copper sample holder between aluminum foil. The sample temperature was controlled by a JUMO IMAGO 500 multichannel process and program controller. Data reduction and analysis, correction or background scattering and transmission were carried out by using the program a2tool (Hasylab).

2.6. Differential Scanning Calorimetry. The DSC measurements were performed with a computer-controlled Phoenix DSC 204 F1 thermal analyzer (Netzsch, Selb, D) with argon as protection gas. The samples were placed in aluminum pans which were cold-sealed under argon. Experimental data are displayed in such a way that exothermic peaks occur at negative heat flow and endothermic peaks at positive heat flow. DSC runs included heating and subsequent cooling at $5{ }^{\circ} \mathrm{C} / \mathrm{min}$. Given temperatures correspond to the onset of the respective thermal process. For the thermotropic liquid crystalline samples, much lower heating and cooling rate were used $\left(1^{\circ} \mathrm{C} / \mathrm{min}\right)$ in order to confirm reproducability between cycles and eliminate the possibility of fractional decomposition. The DSC scans with lower rate are collected in Supporting Information.

2.7. Polarizing Optical Microscopy. The POM pictures of mesophases were acquired with an Axio Imager A1 microscope (Carl Zeiss MicroImaging GmbH, Göttingen, Germany) equipped with a hot stage, THMS600 (Linkam Scientific Instruments Ltd., Surrey, UK), and a Linkam TMS 94 (Linkam Scientific Instruments Ltd., Surrey, UK) temperature controller and crossed polarizers. Images were recorded at a magnification of $100 \times$ as video with a digital camera after initial heating during the cooling stage. Heating and cooling rates were $5 \mathrm{~K} / \mathrm{min}$. For the measurement the samples were placed under argon between two coverslips which were sealed with two-component adhesive (UHU plus 300, UHU GmbH \& Co. KG, Bühl, Germany).

2.8. Density Measurements. Densities of the ILs, which were liquid at room temperature, were determined from ratio of their mass $\mathrm{m}$ to their volume $V$. The ILs were filled into a pycnometer with 0.956 $\mathrm{mL}$ volume (Carl Roth, Karlsruhe, Germany). Mass of the ILs for this volume were obtained by weighting from laboratory scales. The experiments carried out in an argon purged glovebox at $25^{\circ} \mathrm{C}$.

\section{RESULTS AND DISCUSSION}

The salts $[\mathrm{COC} 13] \mathrm{Br},[\mathrm{C} 1 \mathrm{C} 12] \mathrm{Br},[\mathrm{C} 2 \mathrm{C} 11] \mathrm{Br}$ exist as white crystalline solids. [C3C10]Br, [C4C9]Br, [C5C8]Br, [C6C7] $\mathrm{Br}$ were colorless highly viscous liquids.

3.1. Structural Aspects. Crystals of suitable quality for single crystal X-ray structure analysis could be obtained for the salts $[\mathrm{COC} 13] \mathrm{Br}$ and $[\mathrm{C} 2 \mathrm{C} 11] \mathrm{Br}$. Crystallographic data, data collection, and structure refinement details are given in Table 1. The salt $[\mathrm{COC13}] \mathrm{Br}$ crystallizes in the triclinic space group $P \overline{1}$ (No. 2). The asymmetric unit contains one $[\mathrm{COC} 13]^{+}$cation and one $\mathrm{Br}^{-}$as the counterion. The amphiphilic cations are 
Table 1. Crystallographic and Refinement Details for $[\mathrm{COC} 13] \mathrm{Br}$ and $[\mathrm{C} 2 \mathrm{C} 11] \mathrm{Br}$

\begin{tabular}{|c|c|c|}
\hline & {$[\mathrm{COC} 13] \mathrm{Br}$} & {$[\mathrm{C} 2 \mathrm{C} 11] \mathrm{Br}$} \\
\hline Empirical formula & \multicolumn{2}{|c|}{$\mathrm{C}_{16} \mathrm{H}_{30} \mathrm{Br} \mathrm{N} \mathrm{N}_{2}$} \\
\hline Formula weight & \multicolumn{2}{|c|}{330.33} \\
\hline Temperature & \multicolumn{2}{|c|}{$170 \mathrm{~K}$} \\
\hline Crystal system & triclinic & monoclinic \\
\hline Space group & $P \overline{\mathbf{1}}$ & $P 2_{1} / \mathfrak{c}$ \\
\hline \multirow[t]{6}{*}{ Unit cell dimensions } & $a=5.5208(5) \AA$ & $a=17.125(2) \AA$ \\
\hline & $b=7.8840(7) \AA$ & $b=8.2532(7) \AA$ \\
\hline & $c=20.727(2) \AA$ & $c=13.007(1) \AA$ \\
\hline & $\alpha=95.61(1)^{\circ}$ & $\alpha=90^{\circ}$ \\
\hline & $\beta=95.53(1)^{\circ}$ & $\beta=103.10(1)^{\circ}$ \\
\hline & $\gamma=97.86(1)^{\circ}$ & $\gamma=90^{\circ}$ \\
\hline Volume & $883.9(1) \AA^{3}$ & $1790.5(3) \AA^{3}$ \\
\hline $\mathrm{Z}$ & 2 & 4 \\
\hline Calculated density & $1.241 \mathrm{~g} / \mathrm{cm}^{3}$ & $1.228 \mathrm{~g} / \mathrm{cm}^{3}$ \\
\hline Absorption coefficient & $2.317 \mathrm{~mm}^{-1}$ & $2.288 \mathrm{~mm}^{-1}$ \\
\hline$\Theta$-range for data collection & $2.62-24.99^{\circ}$ & $2.75-24.99^{\circ}$ \\
\hline Reflections collected/unique & $7098 / 2624$ & $12051 / 3037$ \\
\hline Refinement method & \multicolumn{2}{|c|}{ Full-matrix least-squares on $F^{2}$} \\
\hline Data/parameters & $2624 / 189$ & $3037 / 174$ \\
\hline Goodness-of-fit on $\mathrm{F}^{2}$ & 1.022 & 0.855 \\
\hline \multirow[t]{2}{*}{ Final $\mathrm{R}$ indices $[I>2 \operatorname{sigma}(I)]$} & $R_{1}=0.0379$ & $R_{1}=0.0515$ \\
\hline & $w R_{2}=0.0906$ & $w R_{2}=0.1000$ \\
\hline \multirow[t]{2}{*}{$\mathrm{R}$ indices (all data) } & $R_{1}=0.0422$ & $R_{1}=0.0919$ \\
\hline & $w R_{2}=0.0919$ & $w R_{2}=0.1100$ \\
\hline
\end{tabular}

characterized by a rod-like shape with one alkyl chain being perpendicular to imidazolium core plane. The alkyl chain and imidazolium core plane form an angle (defined as the angle between the imidazolium ring centroid and the terminal $\mathrm{C}$ atom of alkyl chain) of $92^{\circ}$.

The interdigitated alkyl chains build a bilayer lamellar structure with a repeating layer distance of $20.5 \AA$ (Figure 1, top). The interdigitation is observed in both the crystallo-
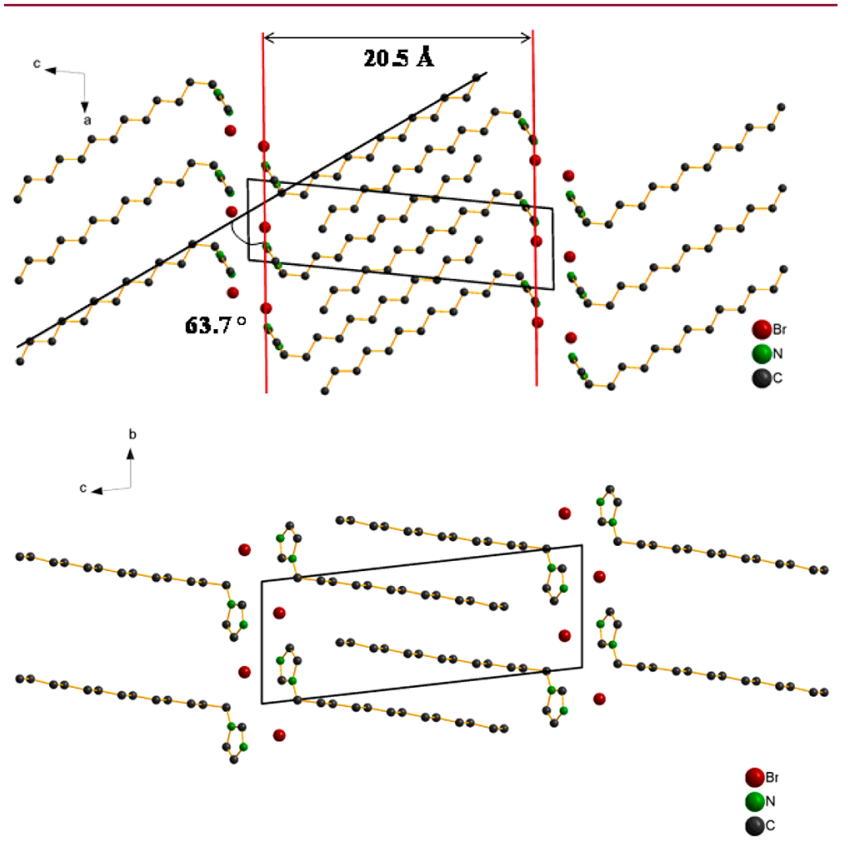

Figure 1. Packing diagram of [COC13]Br. View along crystallographic $b$ axis (top) and $a$ axis (bottom), hydrogen atoms are omitted for clarity. graphic $a c$ and $b c$ planes (Figure 1, bottom). Imidazolium core planes are parallel but shifted with respect to each other, so that no directly face-to-face formation exists. The core planes tilt with respect to the $a b$ plane and form an angle of $30.8^{\circ}$ and the alkyl chains form an angle with the $a b$ plane of $63.7^{\circ}$.

Each imidazolium is further linked with a $\mathrm{Br}^{-}$anion through nonclassical hydrogen bonds. The hydrogen bonds are observed between the bromide ion and all hydrogen atoms of neighboring $\mathrm{C}-\mathrm{H}$ and $\mathrm{N}-\mathrm{H}$. They show distances ranging from 2.64 to $3.01 \AA$. The most significant $\mathrm{Br} \cdots \mathrm{H}-\mathrm{N}$ and $\mathrm{Br} \cdots \mathrm{H}-\mathrm{C} 2$ interactions are highlighted in red in Figure 2. The hydrogen bonding interactions are summarized for clarity in Table 2.

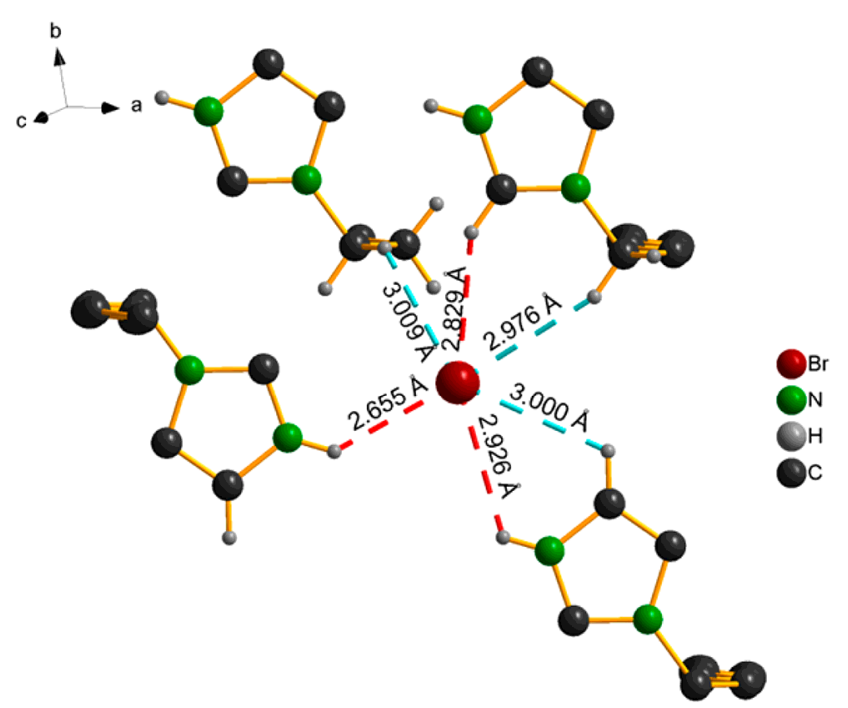

Figure 2. Hydrogen bonding interactions in detail for [ $\mathrm{COC} 13] \mathrm{Br}$. Only interacting hydrogen atoms are shown for clarity. The most significant $\mathrm{H}$-bonds are highlighted in red.

Table 2. Hydrogen Bonds in [COC13] $\mathrm{Br}$ and [C2C11] Br

\begin{tabular}{lcccc} 
& $\mathrm{D}-\mathrm{A} / \AA$ & $\begin{array}{c}\mathrm{D}-\mathrm{H} / \AA \\
{[\mathrm{COC} 13] \mathrm{Br}}\end{array}$ & $\mathrm{H} \cdots \mathrm{A} / \AA$ & $\mathrm{D}-\mathrm{H} \cdots \mathrm{A} / \mathrm{deg}$ \\
$\mathrm{N} 1-\mathrm{H} 1 \cdots \mathrm{Br} \cdot$ & 3.307 & 0.867 & 2.655 & 132.580 \\
$\mathrm{~N} 1^{\prime}-\mathrm{H} 1^{\prime} \cdots \mathrm{Br}$ & 3.469 & 0.867 & 2.926 & 122.190 \\
$\mathrm{C} 4-\mathrm{H} 4 \mathrm{~B} \cdots \mathrm{Br}$ & 3.659 & 0.934 & 3.009 & 127.993 \\
$\mathrm{C} 1-\mathrm{H} 1 \cdots \mathrm{Br}$ & 3.659 & 0.946 & 2.829 & 146.938 \\
$\mathrm{C} 4{ }^{\prime}-\mathrm{H} 4 \mathrm{~A} \cdots \mathrm{Br}$ & 3.840 & 0.936 & 2.976 & 154.207 \\
$\mathrm{C} 2-\mathrm{H} \cdots \mathrm{Br}$ & 3.511 & 0.945 & 3.000 & 115.42 \\
& & {$[\mathrm{C} 2 \mathrm{C} 11] \mathrm{Br}$} & & \\
$\mathrm{C} 4-\mathrm{H} \cdots \mathrm{Br}$ & 3.902 & 0.970 & 3.010 & 153.392 \\
$\mathrm{C} 4{ }^{\prime}-\mathrm{H}^{\prime} \cdots \mathrm{Br}$ & 3.732 & 0.970 & 2.805 & 160.072 \\
$\mathrm{C} 6-\mathrm{H} \cdots \mathrm{Br}$ & 3.775 & 0.970 & 2.877 & 127.993 \\
$\mathrm{C} 1-\mathrm{H} 1 \cdots \mathrm{Br}$ & 3.407 & 0.930 & 2.904 & 115.28 \\
\hline
\end{tabular}

The interdigitation of alkyl chains is observed in both the crystallographic $a b$ and $b c$ planes (Figure 3 ). The cations stack in such a way that their undecyl chains alternate in orientation in neighboring layers, hence forming a bilayer structure. The bilayer spacings are $18.5 \AA$ Å. Imidazolium core planes lie directly face-to-face, but with opposite orientations; while for one the ethyl chain points up, for the other the ethyl group is directed down. Nonclassical hydrogen bonds between cations and anions can be discussed. The $\mathrm{C}-\mathrm{H} \cdots \mathrm{Br}$ interactions are observed with both the $\mathrm{C} 2$ position on imidazolium core and 


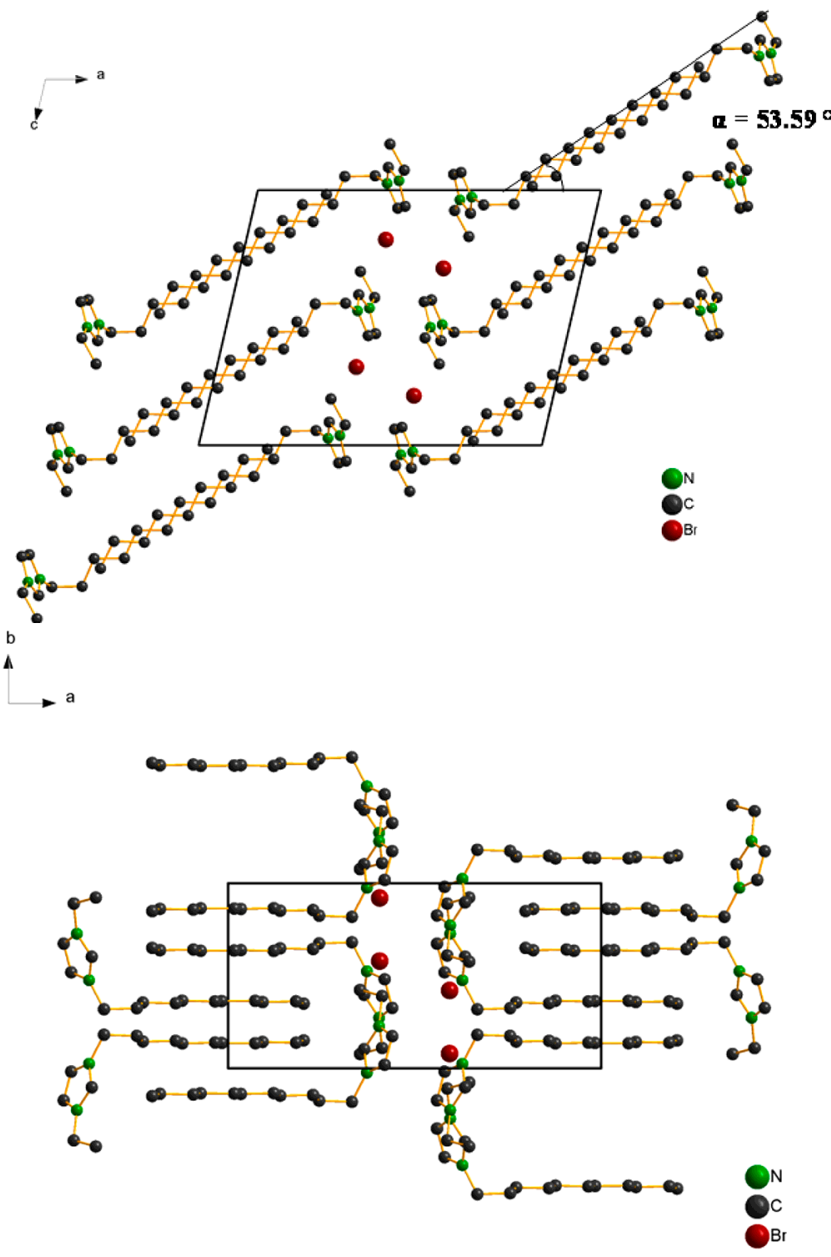

Figure 3. Packing diagrams of $[\mathrm{C} 2 \mathrm{C} 11] \mathrm{Br}$; view along crystallographic $b$ axis (top) and $c$ axis (bottom), hydrogen atoms are omitted for clarity.

starting $\mathrm{C}$ atom on ethyl and undecyl chains. The most significant interactions, which force two imidazolium-rings to align face-to-face are highlighted in red. (Figure 4).

3.2. Thermal Investigations. The thermal properties of all the salts were examined by polarizing optical microscopy (POM) and differential scanning calorimetry (DSC). Thermal transitions are summarized in Table 2.4. [COC13]Br and [C1C12]Br both show liquid crystalline behavior. Each mesophase was identified with POM and SAXS measurements. The DSC scans of $[\mathrm{COC} 13] \mathrm{Br}$ and $[\mathrm{C} 1 \mathrm{C} 12] \mathrm{Br}$ at $5 \mathrm{~K} / \mathrm{min}$ are shown in Figure 5 and 6 (top). The DSC scans obtained from the second heating cycle for these two ILCs are strikingly different from the first run.

In a temperature range from -80 to $160^{\circ} \mathrm{C}$, salt $[\mathrm{COC} 13] \mathrm{Br}$ reveals two reversible phase transitions in the heating cycle. The first heating scan is identical to the second one. A broad endothermic peak is found at $71.3{ }^{\circ} \mathrm{C}$ corresponding to a "melting transition", from a crystalline solid into a liquid crystalline state $(\mathrm{S} \leftrightarrow \mathrm{LC})$, with an enthalpy $\Delta H=34.0 \mathrm{~kJ} / \mathrm{mol}$; a small endothermic peak appears at $141.5^{\circ} \mathrm{C}$ with an enthalpy $\Delta H=0.8 \mathrm{~kJ} / \mathrm{mol}$, belonging to a liquid crystalline $\leftrightarrow$ isotropic liquid ( $\mathrm{LC} \leftrightarrow \mathrm{L}$ ) transition. Between those transitions is a mesophasic region $\left(79-142{ }^{\circ} \mathrm{C}\right)$. Compared to the heating scan, the cooling scan shows an extension of this mesophasic region $\left(140-30{ }^{\circ} \mathrm{C}\right)$, due to inhibited solidification and supercooling.

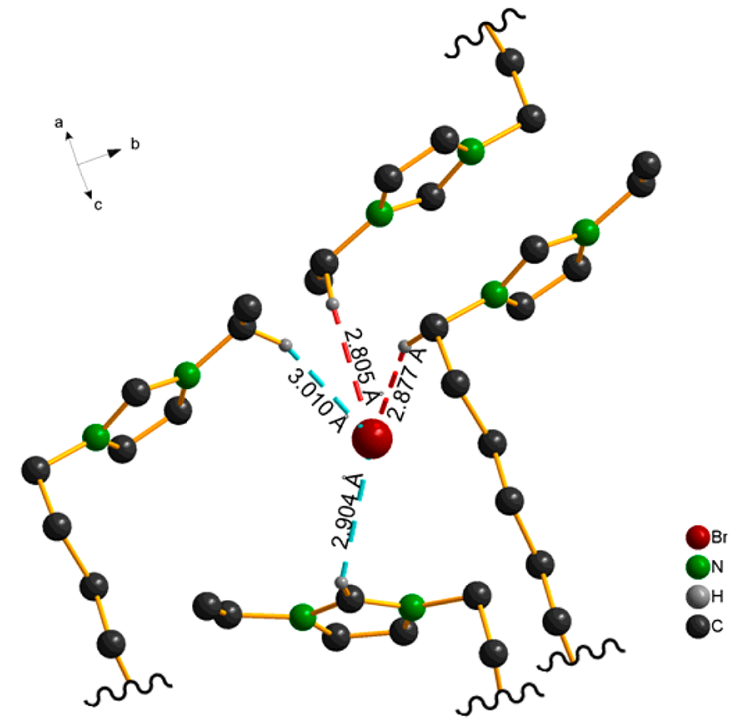

Figure 4. Hydrogen bonding interactions in detail for [C2C11]Br. Only interacting hydrogens are shown for clarity. The most significant $\mathrm{H}$-bonds are highlighted in red.

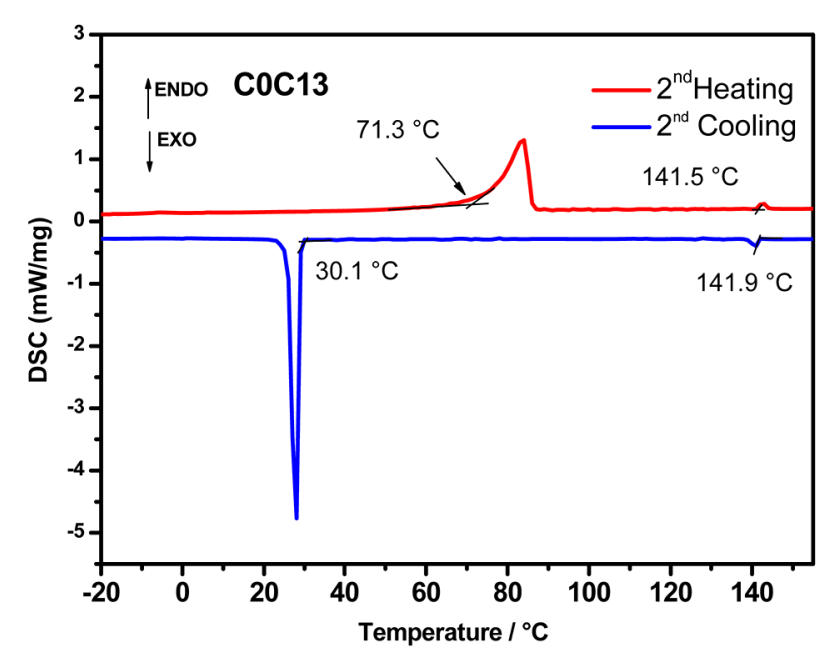

Figure 5. DSC scan for $\mathrm{C} 1 \mathrm{C} 12$ (heating rate: $5{ }^{\circ} \mathrm{C} / \mathrm{min}$ ).

Upon the first heating DSC scan, [C1C12]Br shows two reversible phase transitions. These thermal effects are similar to the scans for [COC13] Br: a crystalline solid $\leftrightarrow$ liquid crystalline $\left(\mathrm{S} \leftrightarrow \mathrm{LC}\right.$ ) transition at $42.5^{\circ} \mathrm{C}$ with an enthalpy $\Delta H=29.7 \mathrm{~kJ} /$ $\mathrm{mol}$; and a liquid crystalline $\leftrightarrow$ isotropic liquid $(\mathrm{LC} \leftrightarrow \mathrm{L})$ transition at $100.5^{\circ} \mathrm{C}$, enthalpy value of this transition is $0.6 \mathrm{~kJ} /$ mol. The reverse transitions of these two thermal effects are revealed in the cooling DSC traces: the phase transition from isotropic liquid to liquid crystalline $(\mathrm{L} \leftrightarrow \mathrm{LC})$ occurs at $100{ }^{\circ} \mathrm{C}$ $(\Delta H=-0.6 \mathrm{~kJ} / \mathrm{mol})$ and a liquid crystalline to crystalline phase $(\mathrm{LC} \leftrightarrow \mathrm{S})$ at $-14.2{ }^{\circ} \mathrm{C}(\Delta H=-6.0 \mathrm{~kJ} / \mathrm{mol})$. An extensive supercooling was observed for the crystallization process. $[\mathrm{C} 1 \mathrm{C} 12] \mathrm{Br}$ exists as liquid crystal at room temperature. The enthalpy value of $L C \leftrightarrow S$ transition is significantly smaller than the value from the heating scan, while the enthalpy value for $\mathrm{LC} \leftrightarrow \mathrm{L}$ phase during the heating is the same as for the cooling.

In contrast, the second heating scan of [C1C12]Br shows complex thermal behavior (Figure 6, top). At $-1.3{ }^{\circ} \mathrm{C}$, a raised baseline is observed. This small endothermic peak is directly followed by two exothermic effects $\left(1.2\right.$ and $\left.5.7^{\circ} \mathrm{C}\right)$. These 

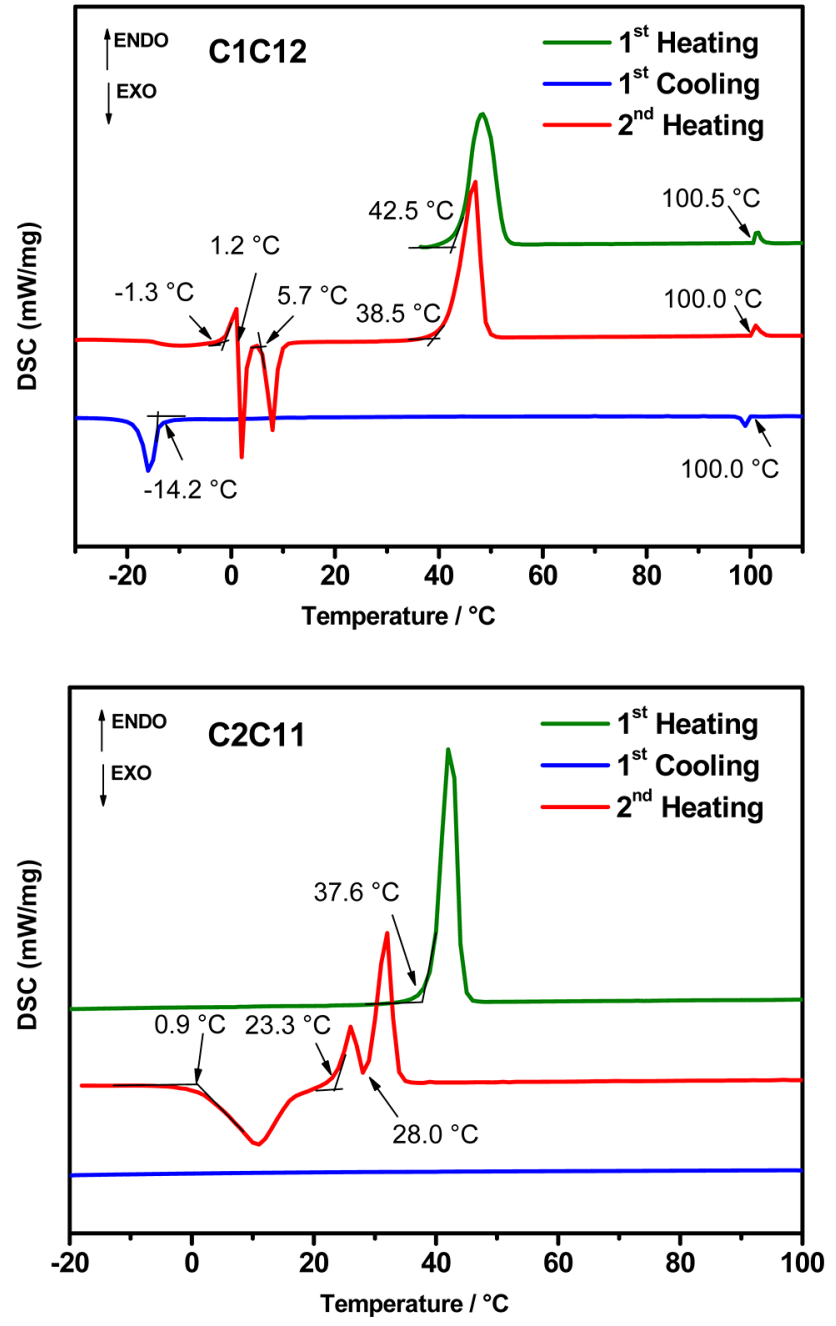

Figure 6. DSC scan for [C1C12] Br (top) and [C2C12]Br (bottom) with heating rate at $5 \mathrm{~K} / \mathrm{min}$. The DSC scan for first heating in this plot is upset by $+0.5 \mathrm{~mW} / \mathrm{mg}$ for clarity.

effects could be determined as solid-solid transitions $(\mathrm{S} \leftrightarrow \mathrm{S})$ by further analytics, such as POM and SAXS. This can be associated to an order-disorder transition of the long alkyl chains. By reducing the heating and cooling rate from 5 to 1 ${ }^{\circ} \mathrm{C} / \mathrm{min}$, these solid-solid transitions split up into two distinct exothermic thermal events at 3.1 and $23.1{ }^{\circ} \mathrm{C}$, respectively (Supporting Information). After the recrystallization process, the $\mathrm{S} \leftrightarrow \mathrm{LC}$ transition occurs at $38.5{ }^{\circ} \mathrm{C}$, followed by $\mathrm{LC} \leftrightarrow \mathrm{L}$ transition at $100^{\circ} \mathrm{C}$. The enthalpy value of both effects $(\Delta H=$ $26.9 \mathrm{~kJ} / \mathrm{mol}$ for $\mathrm{S} \leftrightarrow \mathrm{LC}$ and $\Delta H=0.5 \mathrm{~kJ} / \mathrm{mol}$ for $\mathrm{LC} \leftrightarrow \mathrm{L})$ are similar to the value from the first heating cycle.

$[\mathrm{C} 2 \mathrm{C} 11] \mathrm{Br}$ is obtained as a white crystalline powder. In contrast to $[\mathrm{COC} 13] \mathrm{Br}$ and $[\mathrm{C} 1 \mathrm{C} 12] \mathrm{Br}$, only one sharp endothermic peak at $37.6{ }^{\circ} \mathrm{C}$ is observed upon first heating. This is identified as a melting transition ( $\mathrm{S} \leftrightarrow \mathrm{L}$ ) with an enthalpy $\Delta H=33.2 \mathrm{~kJ} / \mathrm{mol}$. Upon cooling the liquid sample of $[\mathrm{C} 2 \mathrm{C} 11] \mathrm{Br}$ from the isotropic melt to $-50^{\circ} \mathrm{C}$, no transition was observed. Upon heating, the sample undergoes a broad exothermic transition corresponding to a recrystallization at 0 ${ }^{\circ} \mathrm{C}$, followed by two narrow endothermic peaks at 23.3 and 28.0 ${ }^{\circ} \mathrm{C}$. The DSC scans at $5 \mathrm{~K} / \mathrm{min}$ are shown in Figure 6 (bottom). All the further heating cycles are reproducible and are similar to the first cooling and second heating scans.
In contrast to $[\mathrm{COC} 13] \mathrm{Br},[\mathrm{C} 1 \mathrm{C} 12] \mathrm{Br}$ and $[\mathrm{C} 2 \mathrm{C} 11] \mathrm{Br}$, which are solid at room temperature, $[\mathrm{C} 3 \mathrm{C} 10] \mathrm{Br},[\mathrm{C} 4 \mathrm{C} 9] \mathrm{Br}$ and $[\mathrm{C} 5 \mathrm{C} 8] \mathrm{Br},[\mathrm{C} 6 \mathrm{C} 7] \mathrm{Br}$ are viscous liquids. Since their melting points are below room temperature, $[\mathrm{C} 3 \mathrm{C} 10] \mathrm{Br}$, $[\mathrm{C} 4 \mathrm{C} 9] \mathrm{Br},[\mathrm{C5C}] \mathrm{Br}$ and $[\mathrm{C} 6 \mathrm{C} 7] \mathrm{Br}$ are also room temperature ionic liquids (RTILs). The thermal behavior of these RTILs is very similar. They exhibit only glass transitions at very low temperatures. It should be mentioned that for all these salts, the first heating cycles are identical to further heating cycles. Only thermograms of the second heating scans are summarized in Figure 7.
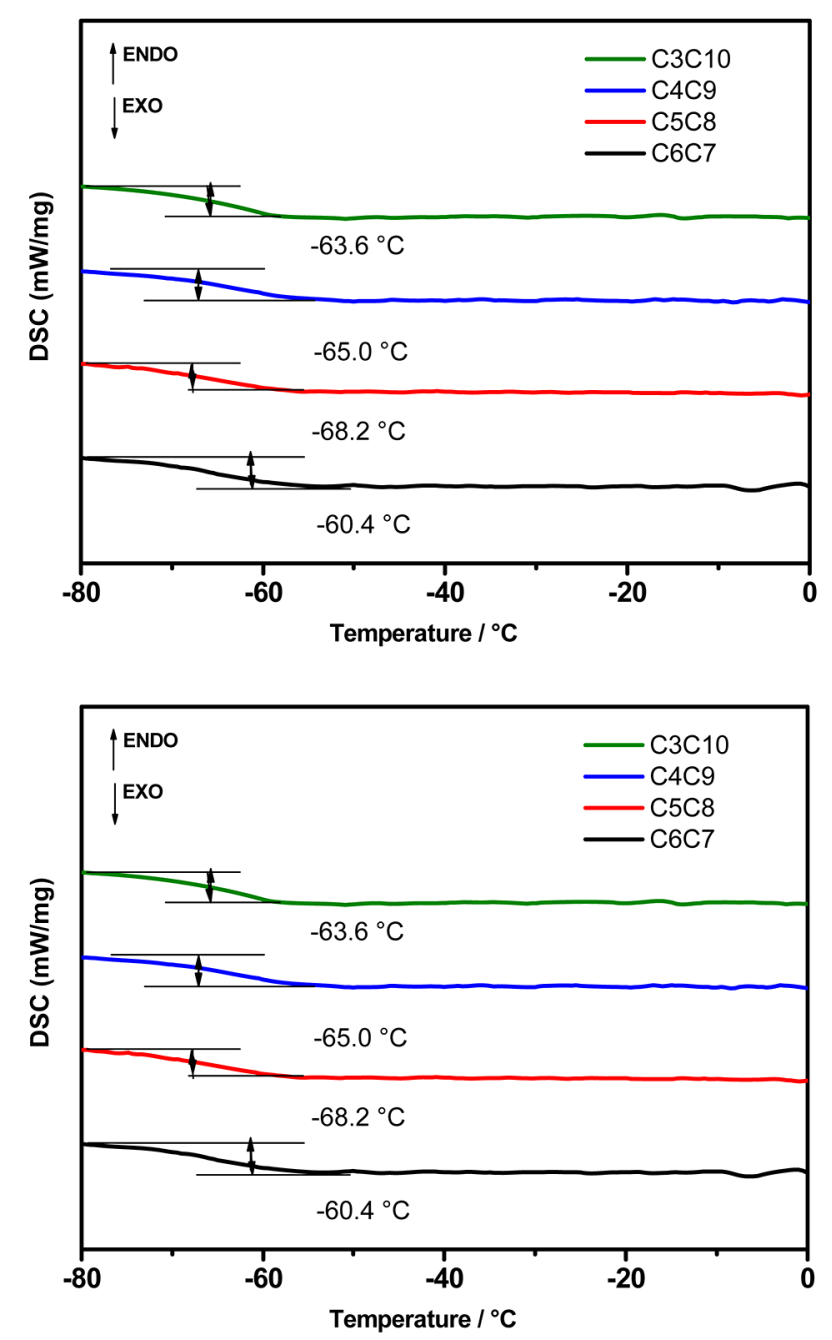

Figure 7. DSC thermograms for $[\mathrm{C} 3 \mathrm{C} 10] \mathrm{Br},[\mathrm{C} 4 \mathrm{C} 9] \mathrm{Br},[\mathrm{C} 5 \mathrm{C} 8] \mathrm{Br}$ and $[\mathrm{C} 6 \mathrm{C} 7] \mathrm{Br}$ (heating rate: $5 \mathrm{~K} / \mathrm{min}$ ), second heating scans (left) and second cooling scans (right).

Salts $[\mathrm{C} 3 \mathrm{C} 10] \mathrm{Br},[\mathrm{C} 4 \mathrm{C} 9] \mathrm{Br}$ and $[\mathrm{C} 5 \mathrm{C} 8] \mathrm{Br}$ show similar glass transition temperatures $\left(T_{\mathrm{g}}\right)$ around $-60{ }^{\circ} \mathrm{C}$, with a remarkable tendency: $T_{\mathrm{g}}$ drops with reducing chain length of the longest alkyl chain. This may be due to the fact that decreasing the alkyl chain length would reduce the attractive van der Waals interactions between the long hydrocarbon chains. In contrast, $[\mathrm{C} 6 \mathrm{C} 7] \mathrm{Br}$, the salt with the shortest alkyl chain length shows a $T_{g}$ at $-57{ }^{\circ} \mathrm{C}$. It is well-known that melting point $\left(T_{\mathrm{m}}\right)$ and glass transition temperature $\left(T_{\mathrm{g}}\right)$ increase with increasing symmetry. ${ }^{19}$ The relatively high $T_{g}$ of $[\mathrm{C} 6 \mathrm{C} 7] \mathrm{Br}$ can be associated with the pseudosymmetry of this salt, which enables more efficient ion-ion packing. 
Glass transition occurs in the case of a hampered crystallization of ILs. Vitrification takes place when a liquid is cooled sufficiently fast to elude crystallization. ${ }^{20}$ For a crystallization process with a well-defined phase transition temperature, an extremely low cooling rate is required. The melting point, $T_{\mathrm{m}}$ of a substance can be related to its glass transition temperature, $T_{\mathrm{g}}$, via many approaches. Since several salts only show glass transitions, while the others show welldefined melting points, for further comparisons, we estimate the melting points $T_{\mathrm{m}}$ of those RTLs from their glass transition temperatures $T_{\mathrm{g}}$ with a simple equation: $T_{\mathrm{g}} \approx 2 / 3 T_{\mathrm{m}}$ (in K). ${ }^{6,21}$ The melting points and the evaluated melting points are plotted versus $n$, the length of longest alkyl chains, as shown in Figure 8. A tendency is immediately noticeable; the melting points

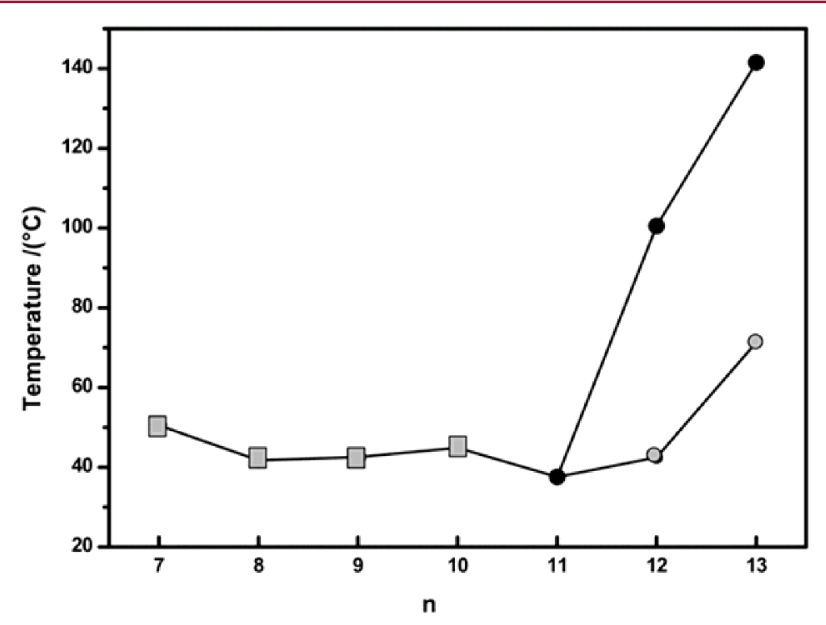

Figure 8. Plot of melting points versus length of the longest alkyl chain $\mathrm{n}$. True melting points, measured from first heating scans, are shown as - the calculated melting points as gray $\mathbf{\square}$, for salts, which form LC phase, the first melting point (crystalline solid $\leftrightarrow$ liquid crystalline $(\mathrm{S} \leftrightarrow \mathrm{LC})$ transition) are as shown as gray

increase with increasing chain length above $n=8$, except for a sudden fall between $n=10$ and $n=11$, although this could be simply due to the inaccuracy of estimating $T_{\mathrm{m}}$ from measured $T_{\mathrm{g}}$ data. The decrease of $T_{\mathrm{m}}$ between $n=7$ and $n=8$ can be explained by the aforementioned symmetry effect, as a higher symmetry leads to a higher melting point. $[\mathrm{C} 6 \mathrm{C} 7] \mathrm{Br}$ is considered as the salt with the highest symmetry in this stady. Interestingly, the characteristic changes in the melting point for $n \geq 8$ follow the same trend observed by Holbrey et al. for 1 alkyl-3-methylimidazolium tetrafluoroborate with asymmetric $\mathrm{N}$-substitution. ${ }^{8}$ The scatter of the data show that the length of the longest has the most dominant effect on the melting point; the influence of cation symmetry is not discernible (see Table 3).

3.3. Mesophase Investigations with POM and SAXS. Liquid crystalline mesophases were observed during the process of heating and cooling only for salts [COC13]Br and [C1C12]Br. Polarizing optical micrographs confirm the temperature ranges and the existence of the aforementioned mesophases. For $[\mathrm{COC} 13] \mathrm{Br}$, an oily streak texture was observed (Figure 9, left) and for $[\mathrm{C} 1 \mathrm{C} 12] \mathrm{Br}$ a focal conic fan texture (Figure 9, right). Both textures are characteristic of a lamellar smectic A phase.

Temperature dependent SAXS data support the assignment of lamellar phases. The primary $d$-spacing peak $\left(d_{(100)}\right)$ represents the average interlayer distance in the lamellar structure. As shown in Figure 10, both salts exhibit layered structures in the crystalline and liquid crystalline phase. Two diffraction peak for $[\mathrm{COC13}] \mathrm{Br}$ emerge in the small-angle region. Both peaks are consistent with a $d$-spacing of $20.5 \AA$ at $25^{\circ} \mathrm{C}$ corresponding to the $(001)$, the most intense peak in the low angle region, and (002) reflections, respectively. This is in agreement with the data from single-crystal XRD. In the mesophase at $90{ }^{\circ} \mathrm{C}$, the layer distance extends to $29 \AA$. This is possibly due to a dispersing alkyl chain arising from the formation of a mesophase, where the rod-like molecules move with respect to one another in the direction of the interdigitated alkyl chains during heating processes. ${ }^{22}$ [C1C12]Br exhibits similar lamellar structures. The calculated layer spacing from the SAXS data are $24 \AA$ for crystalline state and $30 \AA$ in the mesophase. For both salts, an extending layer distance from crystalline state to liquid crystalline state was observed. SAXS data of several $\mathrm{N}$-alkyl-imidazolium ILCs and their LC behavior have been previously reported by Bradley et $\mathrm{al}^{22}$ They suggested two different cation conformations according SAXS data, since single-crystal X-ray data were missing. According our crystal data, the layer spacing in the crystalline state and in the mesophase can be explained by a model shown in Figure 11. However, the thermal transitions and SAXS data from our investigations deviate from the data reported in the literature. The reason for the deviations is the hygroscopic nature of these salts meaning that the previous investigations were carried out using partially hydrated samples. $^{22,23}$

In contrast to $[\mathrm{COC} 13] \mathrm{Br}$ and $[\mathrm{C} 1 \mathrm{C} 12] \mathrm{Br}$, the salt $[\mathrm{C} 2 \mathrm{C} 11]$ $\mathrm{Br}$ exhibits no $\mathrm{LC}$ behavior. The single crystal data provides an insight into the relationship between structure and the likelihood of a mesophase formation before melting and allows to reason why in that case no mesophase is adopted. As previously mentioned, the positively charged imidazolium rings are forced by $\mathrm{H}$-bonds to align directly face-to-face conformations (Figures 3 and 4). It might be argued that the elimination of liquid crystallinity is a consequence of this faceto-face conformation: The structure would expand during the heating process due to additional thermal energy. This would induce two positively charged imidazolium planes to move closer to each other and lead to a repulsive force between the layers. As a result, the attractive van der Waals interaction between the alkyl chain stacks is not strong enough to stabilize a liquid crystalline state when less than 12 carbon atoms are involved in the chain, and the salt melts directly into an isotropic liquid without exhibiting mesomorphic properties. A representative illustration is shown in Figure 12.

3.4. Physical Properties: Densities and Viscosities. Temperature-dependent viscosity measurements indicate that the symmetry of the cation affects viscosity of these ILs (Figure 13). $[\mathrm{C} 3 \mathrm{C} 10] \mathrm{Br}$ and $[\mathrm{C} 4 \mathrm{C} 9] \mathrm{Br}$ with similarly asymmetric cations are more viscous than $[\mathrm{C} 5 \mathrm{C} 8] \mathrm{Br}$ and $[\mathrm{C} 6 \mathrm{C} 7] \mathrm{Br}$. Salt $[\mathrm{C} 5 \mathrm{C} 8] \mathrm{Br}$ reveals the same viscosity as $[\mathrm{C} 3 \mathrm{C} 10] \mathrm{Br}$ and $[\mathrm{C} 4 \mathrm{C} 9] \mathrm{Br}$ below $35^{\circ} \mathrm{C}$. Above $35^{\circ} \mathrm{C}$, the viscosity of [C5C 8$] \mathrm{Br}$ decreases dramatically with increasing temperature. For example, the viscosity decreases $40 \%$ by a temperature change from 35 to $40{ }^{\circ} \mathrm{C}$. [C6C7]Br, the pseudosymmetrical IL, surprisingly shows the lowest viscosity. It is well-know that highly asymmetric cations exhibit lower viscosities. ${ }^{24}$ The results here could be explained as a consequence of an alkyl tail segregation, ${ }^{25}$ which has been indicated by SWAXS (short and wide-angle X-ray scattering) data and MD (molecular dynamic) simulations. Alkyl tail segregation denotes the formation of 
Table 3. Thermal Behavior of Ionic Liquids and Ionic Liquid Crystals ${ }^{a, b, c}$

\begin{tabular}{|c|c|c|c|}
\hline compound & phase transition beh & havior & \\
\hline$[\mathrm{COC} 13] \mathrm{Br}$ & $\mathrm{Cr} \underset{30.1(-36.7)}{\stackrel{71.3(34.0)}{\rightleftharpoons}} \operatorname{SmA} \underset{141.9(-0.7)}{\stackrel{141.5(0.8)}{\rightleftharpoons}}$ Iso & & \\
\hline \multicolumn{4}{|l|}{$[\mathrm{C} 1 \mathrm{C} 12] \mathrm{Br}$} \\
\hline 1st thermal cycle & $\mathrm{Cr} \underset{-14.2(-6.0)}{\stackrel{42.5(29.7)}{\rightleftharpoons}} \operatorname{SmA} \underset{100.0(-0.6)}{\stackrel{100.5(0.6)}{\rightleftharpoons}}$ Iso & & \\
\hline 2nd thermal cycle & $\mathrm{Cr} \stackrel{(3.6)}{\longrightarrow} \mathrm{Cr}^{\prime} \stackrel{\stackrel{1.2}{(-6.6)} \longrightarrow}{\longrightarrow} \mathrm{Cr}^{\prime \prime} \stackrel{(-6.3)}{\longrightarrow} \mathrm{Cr}^{\prime \prime}$ & $\underset{\substack{-14.2 \\
(-6.0)}}{\stackrel{(26.9)}{\rightleftharpoons}} \operatorname{SmA} \underset{\substack{180.9 \\
(-0.6)}}{\stackrel{100.0}{(0.5)}} \mathrm{Iso}$ & \\
\hline$[\mathrm{C} 2 \mathrm{C} 11] \mathrm{Br}$ & $\mathrm{Cr} \underset{1^{5} \text { thermal cycle }}{\stackrel{37.6(33.2)}{\longrightarrow}}$ Iso & & 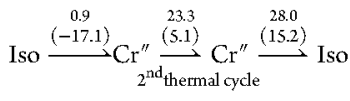 \\
\hline$[\mathrm{C} 3 \mathrm{C} 10] \mathrm{Br}^{d}$ & Glass $\underset{-63.6(0.28)}{\stackrel{-61.1(0.73)}{\rightleftharpoons}}$ Iso & & \\
\hline$[\mathrm{C} 4 \mathrm{C} 9] \mathrm{Br}^{d}$ & Glass $\underset{-65.0(0.27)}{\stackrel{-62.7(0.67)}{\rightleftharpoons}}$ Iso & & \\
\hline$[\mathrm{C} 5 \mathrm{C} 8] \mathrm{Br}^{d}$ & Glass $\underset{-68.2(0.26)}{\stackrel{-63.2(0.68)}{\rightleftharpoons}}$ Iso & & \\
\hline$[\mathrm{C} 6 \mathrm{C} 7] \mathrm{Br}^{d}$ & Glass $\underset{-60.4(0.26)}{\stackrel{-57.4(0.19)}{\rightleftharpoons}}$ Iso & & \\
\hline
\end{tabular}

${ }^{a}$ Phase-transition temperatures $\left({ }^{\circ} \mathrm{C}\right)$ and enthalpies $\left(\mathrm{kJ} / \mathrm{mol}\right.$, in parentheses) are measured during heating and cooling at $5 \mathrm{~K} / \mathrm{min} .{ }^{b}$ Values were determined from the second heating cycle if not mentioned, in this case, the thermal behavior was identical for all three heating cycles. ${ }^{c}$ Phase transitions were identified by POM and SAXS measurements. ${ }^{d}$ These values are given as $T_{\mathrm{g}}$ : glass transition temperatures $\left({ }^{\circ} \mathrm{C}\right)$ and heat capacity changes at $T_{\mathrm{g}}\left(\mathrm{J} / \mathrm{K}^{-1} \mathrm{~g}^{-1}\right)$ are given in parentheses. $\mathrm{Cr}=$ crystalline phase, $\mathrm{LC}=$ smectic-A phase, Iso $=$ isotropic phase.
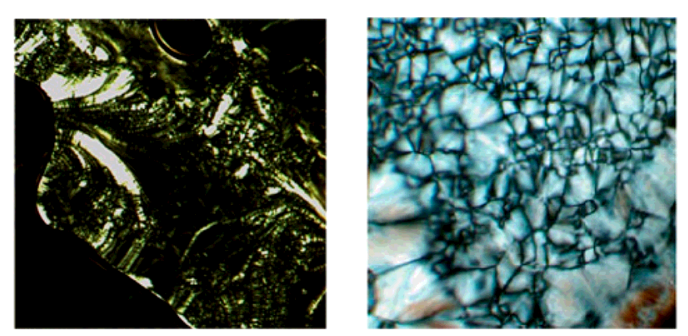

Figure 9. Representative $\mathrm{POM}$ images of thermotropic liquid crystalline phases of $[\mathrm{COC} 13] \mathrm{Br}$ and $[\mathrm{C} 1 \mathrm{C} 12] \mathrm{Br}:[\mathrm{COC} 13] \mathrm{Br}$ at 105 ${ }^{\circ} \mathrm{C}$ (left) and $[\mathrm{C} 1 \mathrm{C} 12] \mathrm{Br}$ at $67^{\circ} \mathrm{C}$ (right).
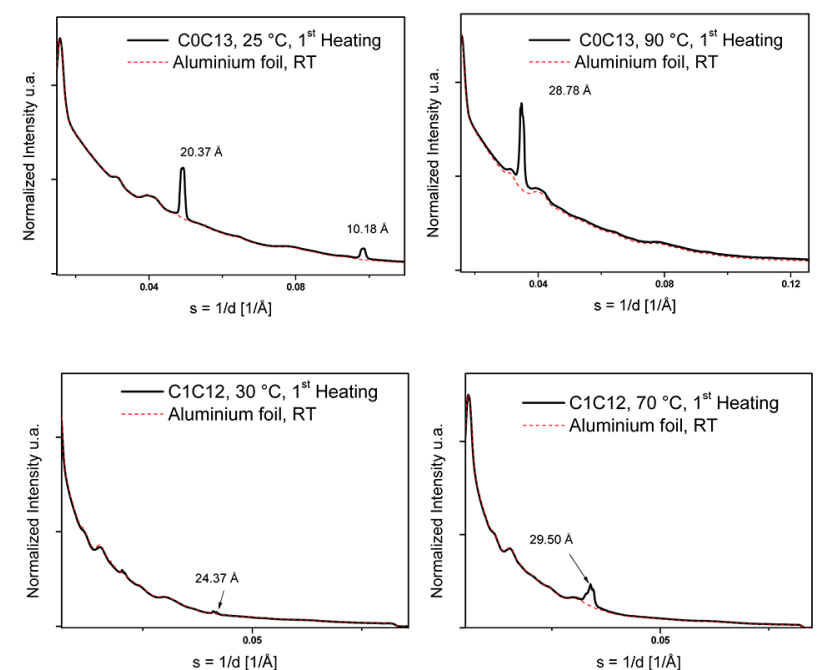

Figure 10. SAXS patterns for [COC13] Br at $25{ }^{\circ} \mathrm{C}$ (top, left) and 90 ${ }^{\circ} \mathrm{C}$ (top, right) and (b) $[\mathrm{C} 1 \mathrm{C} 12] \mathrm{Br}$ at $30{ }^{\circ} \mathrm{C}$ (bottom, left) and $70{ }^{\circ} \mathrm{C}$ (bottom, right), respectively.
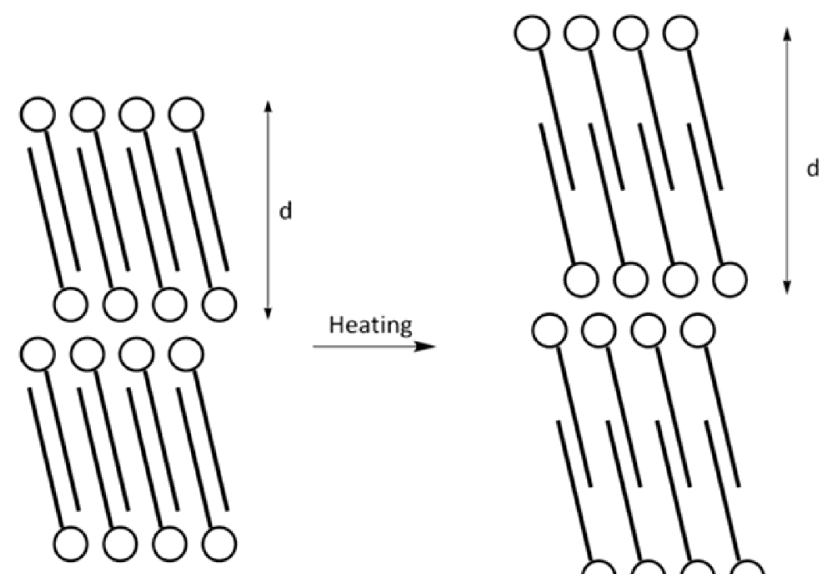

Crystal

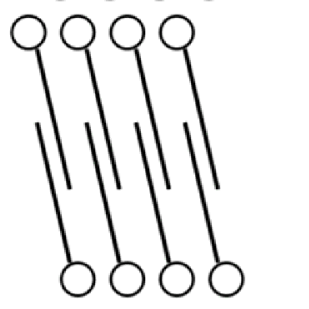

Mesophase

Figure 11. Illustration of the change in molecular arrangement of $[\mathrm{COC} 13] \mathrm{Br}$ and $[\mathrm{C} 1 \mathrm{C} 12] \mathrm{Br}$ from the crystalline state to the mesophase.

structurally heterogeneous domains: polar regions with cation rings and anions and nonpolar regions formed by alkyl groups.

The densities of the ILs are given in Table 4. The densities of all four ILs are approximately identical at $\rho=1.09 \mathrm{~g} \mathrm{~mL}^{-1}$ when considering experimental error. This result is consistent with the observation that the density of ILs increases by almost proportionately with increasing molecular size. ${ }^{26}$

\section{CONCLUSIONS}

A series of asymmetric 1,3- $n$-dialkylimidazolium bromides with the same molecular weight and empirical formula, $\mathrm{C}_{16} \mathrm{H}_{30} \mathrm{BrN}_{2}$, were synthesized. Physicochemical properties such as thermal transitions, density, and viscosities of all the salts were 


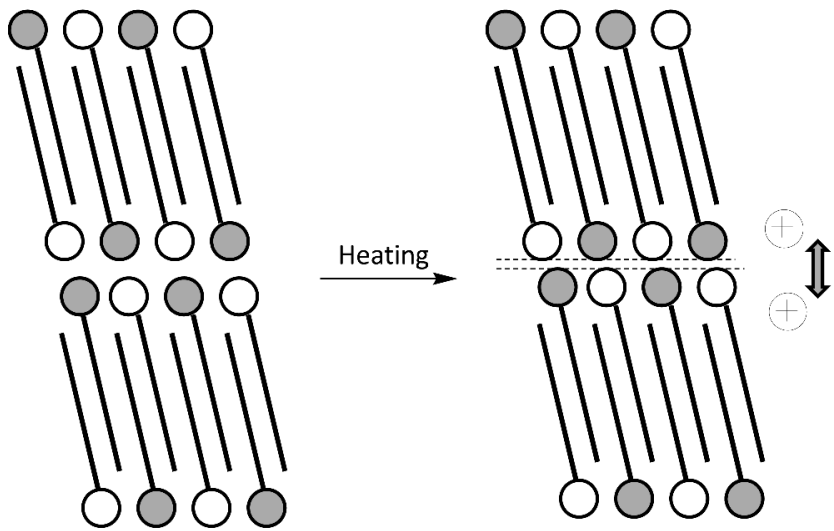

Figure 12. Schematic representation of $[\mathrm{C} 2 \mathrm{C} 11] \mathrm{Br}$ : the directly faceto-face conformation of the imidazolium cores eliminates a mesophase formation, owning to repulsive forces between the layers caused by the positively charged regions moving toward each other.

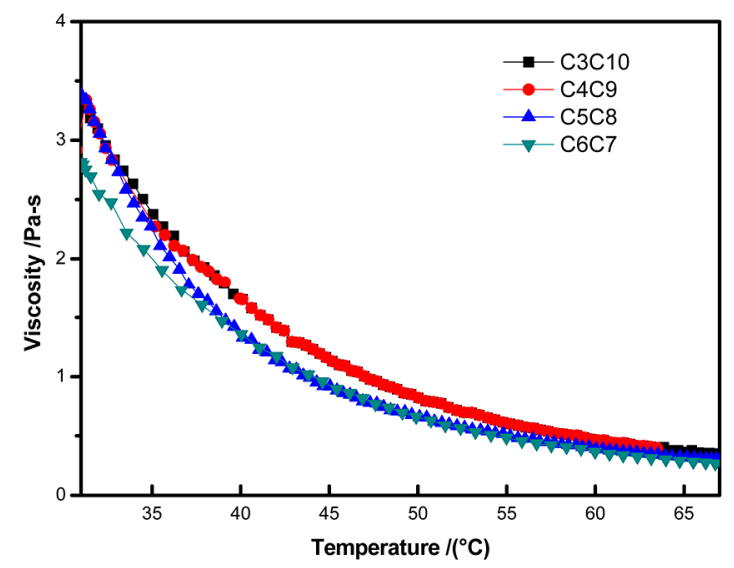

Figure 13. Comparison of temperature dependent viscosity data for $[\mathrm{C} 3 \mathrm{C} 10] \mathrm{Br},[\mathrm{C} 4 \mathrm{C} 9] \mathrm{Br},[\mathrm{C} 5 \mathrm{C} 8] \mathrm{Br}$ and $[\mathrm{C} 6 \mathrm{C} 7] \mathrm{Br}$.

Table 4. Densities of RTILs
\[ \begin{array}{lcccc}\boldsymbol{C} & & & \\ \\ \text { Density }\left[\mathrm{g} \mathrm{mL}^{-1}\right] & 1.089 & 1.085 & 1.085 & 1.086 \\ { }^{a} \text { At } 25{ }^{\circ} \mathrm{C} . & & & & \end{array} \]

investigated. Crystals of sufficient quality for X-ray structure analysis could be obtained from $[\mathrm{COC} 13] \mathrm{Br}$ and $[\mathrm{C} 2 \mathrm{C} 11] \mathrm{Br}$. Our study can be summarized in the following aspects.

(a). All of these salts are ILs, since they have a melting point below $100^{\circ} \mathrm{C}$. Salts $[\mathrm{COC} 13] \mathrm{Br},[\mathrm{C} 1 \mathrm{C} 12] \mathrm{Br}$ and $[\mathrm{C} 2 \mathrm{C} 11] \mathrm{Br}$ exist as (thermodynamically stable) crystalline solids at room temperature, while $[\mathrm{C} 3 \mathrm{C} 10] \mathrm{Br},[\mathrm{C} 4 \mathrm{C} 9] \mathrm{Br},[\mathrm{C} 5 \mathrm{C} 8] \mathrm{Br}$ and $[\mathrm{C} 6 \mathrm{C} 7] \mathrm{Br}$ are room temperature ionic liquids with high viscosities. Furthermore, thermotropic liquid crystalline behavior for $[\mathrm{COC} 13] \mathrm{Br}$ and $[\mathrm{ClC} 12] \mathrm{Br}$ can be observed. The liquid crystalline properties of these two salts were examined by differential scanning calorimetry and polarized optical microscopy. The mesophases that they form can be identified with POM images and X-ray scattering experiments at small angle range as the $\operatorname{SmA}$ phase for both salts.

(b). One characteristic of ILs is that the melting point $\left(T_{\mathrm{m}}\right)$ and glass transition temperature $\left(T_{\mathrm{g}}\right)$ increase with increasing symmetry. ${ }^{19}$ Our results are consistent with this fact. For instance, salt $[\mathrm{C} 6 \mathrm{C} 7] \mathrm{Br}$ with pseudosymmetry shows a relatively high $T_{\mathrm{g}}$ compared to the other RTILs with lower symmetry in this study. For $n \geq 11$, where $n$ is the length of the longest alkyl chain, the $T_{\mathrm{m}}$ increases with increasing $n$. This can be explained by considering the increasing van der Waals forces between the long alkyl chains. The thermal behavior of the asymmetric dialkyl-imidazolium ILs shows the same trend as previously observed for 1-alkyl-3-methylimidazolium tetrafluoroborates. This can be rationalized in terms of the influence of the length of the longest alkyl chain on the thermal behavior dominating symmetry effects.

(c). Crystal structure analyses show for both $[\mathrm{COC} 13] \mathrm{Br}$ and [C2C11]Br a bilayer lamellar structure. Remarkably, a separation of hydrophobic (alkyl chains stacks) and hydrophilic (imidazolium head groups) groups in the cations was observed for both salts, although only [COC13] shows thermotropic mesophase formation. This indicates that for a LC phase to exist, not only are the calamitic shape and integral length of a molecule important but also a minimal chain length of $n=12$ is required. It has previously been reported that [C1C11]I exhibits no LC phase. ${ }^{27}$ This dodecyl unit realizes the balance between the van der Waals interactions and electrostatic repulsion, opening the door to mesophase formation. Therefore, a dodecyl group could be considered as a functional group responsible for liquid crystalline behavior. Furthermore, it could be considered that a face-to-face conformation of imidazolium core planes hinders mesophase formation in the case of short chain imidazolium salts. Further experiments on imidazoliumbased ILs bearing a dodecyl group with different sizes and symmetries will be required to confirm this observation.

(d). The fact that the viscosities of the RTILs drop with increasing symmetry is a consequence of a alkyl tail segregation, which was reported previously. The RTILs show almost the same density of $\rho=1.09 \mathrm{~g} \mathrm{~mL}^{-1}$, which is rationalized in terms of the same size and molecular weight of all the salts.

\section{ASSOCIATED CONTENT}

\section{S Supporting Information}

Supplemental figures and crystallographic data. This material is available free of charge via the Internet at http://pubs.acs.org.

\section{AUTHOR INFORMATION}

\section{Corresponding Author}

*E-mail: anja.mudring@ruhr-uni-bochum.de. Tel: +49-234-3227408.

\section{Notes}

The authors declare no competing financial interest.

\section{ACKNOWLEDGMENTS}

This work was supported by the German Science Foundation DFG through the priority program 1191 "Ionic Liquids", the DFG Cluster of Excellence RESOLV and the DESY (Deutsches Elektronensynchrotron proposal no. I-20100011). We thank Dr. Sergio Funari, for support during the SAXS measurements and thank Dr. P.Campbell for helpful comments.

\section{REFERENCES}

(1) (a) Binnemans, K. Ionic Liquid Crystals. Chem. Rev. 2005, 105, 4148-4204. (b) Getsis, A.; Mudring, A.-V. Imidazolium based ionic liquid crystals: structure, photophysical and thermal behavior of [Cnmim]Br.xH2O ( $\mathrm{n}=12,14 ; \mathrm{x}=0$, 1). Cryst. Res. Technol. 2008, 43, $1187-1196$.

(2) Goodby, J. W. In Phase structures of calamitic liquid crystals; WileyVCH Verlag GmbH: New York, 1998; pp 3-21. 
(3) Collings, P.; Hird, M., An Introduction to Liquid Crystals: Chemistry and Physics; CRC Press: Boca Raton, FL, 1997; p 300.

(4) Axenov, K. V.; Laschat, S. Thermotropic ionic liquid crystals. Materials 2011, 4, 206-259.

(5) Welton, T. Room-temperature ionic liquids. Solvents for synthesis and catalysis. Chem. Rev. 1999, 99, 2071-2083.

(6) Mudring, A.-V. Solidification of ionic liquids: Theory and techniques. Aust. J. Chem. 2010, 63, 544-564.

(7) Plechkova, N. V.; Seddon, K. R. Applications of ionic liquids in the chemical industry. Chem. Soc. Rev. 2008, 37, 123-150.

(8) Holbrey, J. D.; Seddon, K. R. The phase behaviour of 1-alkyl-3methylimidazolium tetrafluoroborates; ionic liquids and ionic liquid crystals. J. Chem. Soc., Dalton Trans. 1999, 2133-2140.

(9) Getsis, A.; Mudring, A. V. 1-Dodecyl-3-methylimidazolium bromide monohydrate. Acta Crystallogr., Sect. E: Struct. Rep. Online 2005, E61, o2945-o2946.

(10) Goossens, K.; Nockemann, P.; Driesen, K.; Goderis, B.; Goerller-Walrand, C.; Van, H. K.; Van, M. L.; Pouzet, E.; Binnemans, K.; Cardinaels, T. Imidazolium ionic liquid crystals with pendant mesogenic groups. Chem. Mater. 2008, 20, 157-168.

(11) Blesic, M.; Swadzba-Kwasny, M.; Belhocine, T.; Gunaratne, H. Q. N.; Lopes, J. N. C.; Gomes, M. F. C.; Padua, A. A. H.; Seddon, K. R.; Rebelo, L. P. N. 1-Alkyl-3-methylimidazolium alkanesulfonate ionic liquids, $[\mathrm{CnH} 2 \mathrm{n}+1 \mathrm{mim}][\mathrm{CkH} 2 \mathrm{k}+1 \mathrm{SO} 3]$ : synthesis and physicochemical properties. Phys. Chem. Chem. Phys. 2009, 11, 8939-8948.

(12) Blesic, M.; Swadzba-Kwasny, M.; Holbrey, J. D.; Canongia, L. J. N.; Seddon, K. R; Rebelo, L. P. N. New catanionic surfactants based on 1-alkyl-3-methylimidazolium alkylsulfonates, $[\mathrm{CnH} 2 \mathrm{n}+1 \mathrm{mim}]$ [CmH2m+1SO3]: mesomorphism and aggregation. Phys. Chem. Chem. Phys. 2009, 11, 4260-4268.

(13) Lopes, J. N. C.; Gomes, M. F. C.; Padua, A. A. H. Nonpolar, polar, and associating solutes in ionic liquids. J. Phys. Chem. B 2006, $110,16816-16818$.

(14) Wang, Y.; Voth, G. A. Tail aggregation and domain diffusion in ionic liquids. J. Phys. Chem. B 2006, 110, 18601-18608.

(15) (a) Prechtl, M. H. G.; Campbell, P. S.; Scholten, J. D.; Fraser, G. B.; Machado, G.; Santini, C. C.; Dupont, J.; Chauvin, Y. Imidazolium ionic liquids as promoters and stabilizing agents for the preparation of metal $(0)$ nanoparticles by reduction and decomposition of organometallic complexes. Nanoscale 2010, 2, 2601-2606. (b) Helgadottir, I. S.; Arquilliere, P. P.; Campbell, P. S.; Santini, C. C.; Haumesser, P. H. Novel chemical route to size-controlled $\mathrm{Ta}(0)$ and $\mathrm{Ru}-\mathrm{Ta}$ nanoparticles in ionic liquids. MRS Online Proc. Libr. 2012, 1473, DOI: 10.1557/opl.2012.1518. (c) Richter, K.; Birkner, A; Mudring, A.-V. Stabilizer-free metal nanoparticles and metal-metal oxide nanocomposites with long-term stability prepared by physical vapor deposition into ionic liquids. Angew. Chem., Int. Ed. 2010, 49, 24312435.

(16) Dzyuba, S. V.; Bartsch, R. A. New room-temperature ionic liquids with $\mathrm{C} 2$-symmetrical imidazolium cations. Chem. Commun. 2001, 1466-1467.

(17) Wang, X; Heinemann, F. W.; Yang, M.; Melcher, B. U.; Fekete, M.; Mudring, A.-V.; Wasserscheid, P.; Meyer, K. A new class of double alkyl-substituted, liquid crystalline imidazolium ionic liquids - a unique combination of structural features, viscosity effects, and thermal properties. Chem. Commun. 2009, 7405-7407.

(18) Dzyuba, S. V.j Bartsch, R. A. Influence of structural variations in 1-alkyl(aralkyl)-3-methylimidazolium hexafluorophosphates and bis(trifluoromethyl-sulfonyl)imides on physical properties of the ionic liquids. ChemPhysChem 2002, 3, 161-166.

(19) Holbrey, J. D.; Rogers, R. D. Physicochmical properties of ionic liquid. In Ionic Liquid in Synthesis; Wasserscheid, P., Welton, T., Eds.; Wiley-VCH: Weinheim, 2008; Vol. 1, pp 57-88.

(20) Angell, C. A. Structural instability and relaxation in liquid and glassy phases near the fragile liquid limit. J. Non-Cryst. Solids 1988, 102, $205-21$.

(21) Hunt, A. A simple connection between the melting temperature and the glass temperature in a kinetic theory of the glass transition. $J$. Phys.: Condens. Matter 1992, 4, L429-L431.
(22) Bradley, A. E.; Hardacre, C.; Holbrey, J. D.; Johnston, S.; McMath, S. E. J.; Nieuwenhuyzen, M. Small-angle X-ray scattering studies of liquid crystalline 1-alkyl-3-methylimidazolium salts. Chem. Mater. 2002, 14, 629-635.

(23) Getsis, A.; Mudring, A.-V. Lanthanide containing ionic liquid crystals: EuBr2, SmBr3, TbBr3 and $\mathrm{DyBr} 3$ in $\mathrm{C} 12 \mathrm{mimBr}$. Z. Anorg. Allg. Chem. 2010, 636, 1726-1734.

(24) Willes, J. S.; Levisky, J. A.; Wilson, R. A.; Hussey, C. L. Dialkylimidazolium chloroaluminate melts: a new class of roomtemperature ionic liquids for electrochemistry, spectroscopy and synthesis. Inorg. Chem. 1982, 21, 1263-1264.

(25) Zheng, W.; Mohammed, A.; Hines, L. G.; Xiao, D.; Martinez, O. J.; Bartsch, R. A.; Simon, S. L.; Russina, O.; Triolo, A.; Quitevis, E. L. Effect of cation symmetry on the morphology and physicochemical properties of imidazolium ionic liquids. J. Phys. Chem. B 2011, 115, $6572-6584$.

(26) Rebelo, L. P. N.; Najdanovic-Visak, V.; Gomes, d. A. R; Esperanca, J. M. S. S.; Nunes, d. P. M.; Guedes, H. J. R; Visak, Z. P.; de, S. H. C.; Szydlowski, J.; Canongia, L. J. N.; Cordeiro, T. C. Phase behavior and thermodynamic properties of ionic liquids, ionic liquid mixtures, and ionic liquid solutions. ACS Symp. Ser. 2005, 901, 270291.

(27) Yamanaka, N.; Kawano, R; Kubo, W.; Kitamura, T.; Wada, Y.; Watanabe, M.; Yanagida, S. Ionic liquid crystal as a hole transport layer of dye-sensitized solar cells. Chem. Commun. 2005, 740-742. 